\title{
C-14 SIDI AÏSSA GEODYNAMIC EVOLUTION DURING NEOGEN AND ITS IMPACT ON THE OUED GUETRERINI FIELD MESO-CENOZOIC PETROLEUM SYSTEM
}

H.L. KHEIDRI', B. KHATIR' AND F. BELFAR ${ }^{2}$

'Sonatrach, EXP. Avenue du 1 Novembre, bt C, Bp 68M. Boumerdès 35000, Algeria ${ }^{2}$ Houari Boumediène Université des Sciences et Technologie

\begin{abstract}
Oued Gueterini field (Sidi Aïssa area) constitutes the first discovered oil field in Algeria producing from the tellian nappes. The understanding of its petroleum system and neogen evolution gives a wide path to the petroleum exploration in the alpine domain of Algeria.

During lower Miocene, the study area behaves as a foreland basin, displaying significant lateral facies variations, accompanied by a week hydrocarbon generation.

During the middle Miocene, the area is affected by transtension movement witnessed by shelf marly limestone in the north grading laterally to deltafront shaly sandstone southward, then tidal to fluvial influenced deltaic facies. This event, before being ended by nappe emplacement, is characterized by deep heating added to lifting and nappe loading. That leads to a new distribution of Oued Gueterini hydrocarbons and switch on the generation from Cenozoic, Eocene - Paleocene source rocks in the area.

During the upper Miocene all the area is affected by compression. The effect of this event is the structuration of tellian nappes and their underlying autochtonous formations. This led to a generation acceleration with an increasing of Cenozoic source rock contribution, tertiary migration and seeping of hydrocarbons.
\end{abstract}

Introduction : The area of Sidi Aissa belongs to the Maghrebides outer zones, the southern section of the Alpine foldbelt.It is located across the tellian nappes in the north and foreland hodnean type in the south. This latter disappears northward under the tellian nappes (Fig 1).

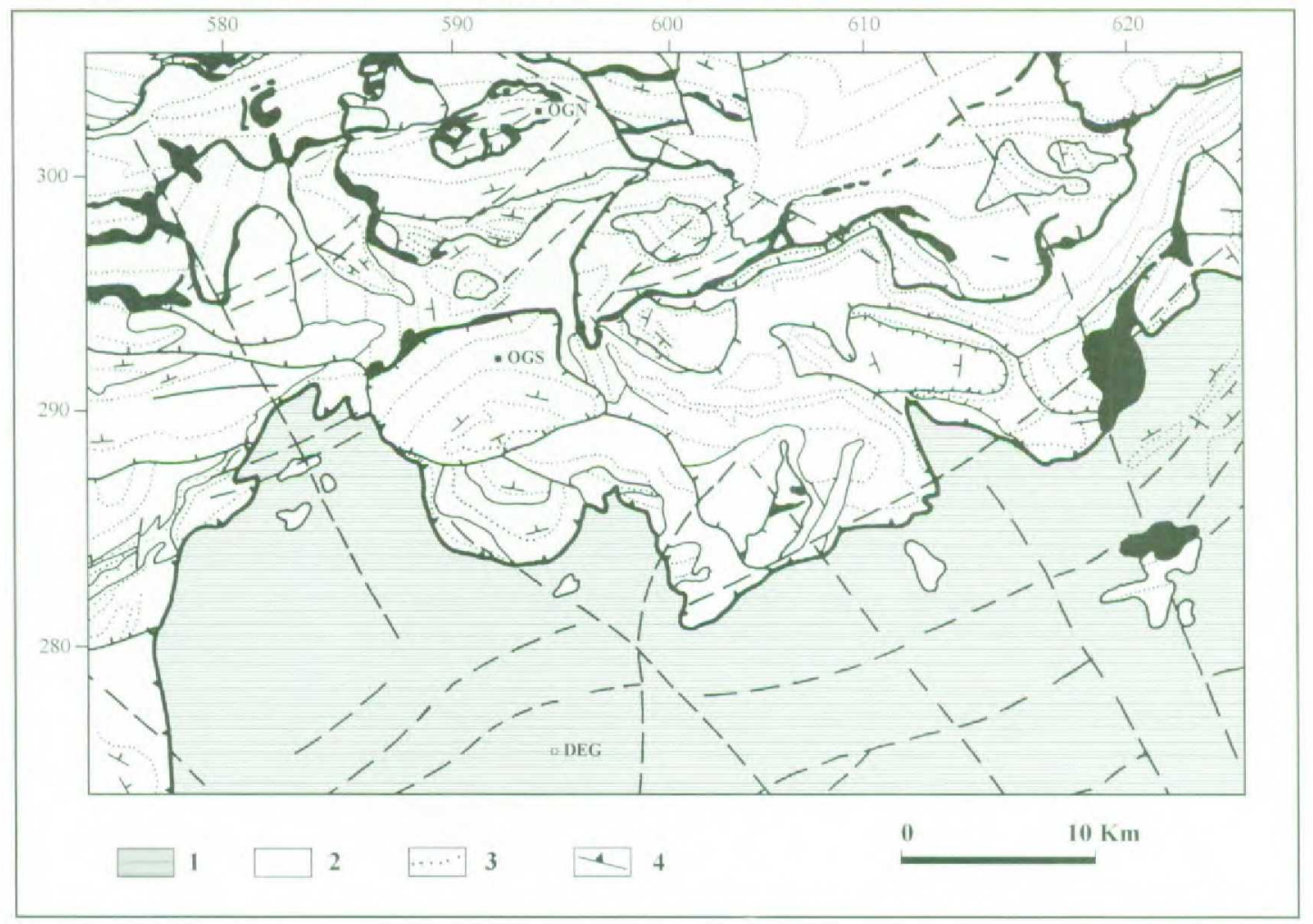

Fig 1:Geological map showing the location of the study area.

1: Foreland. 2: Tellian nappes. 3: Beds. 4: Tellian nappes thrusting. 
The Eocene limestones in the tellian nappes constitute the main reservoirs, levels A and B of Oued Gueterini field. The area source rock is not well known, but it is thought to be of Cenomano-Turonian age, as the case of the productive zone of south-east Constantine area. During the miocene, this zone was considered by earlier authors, as a very subsiding furrow « south tellian furrow » area of molassique sedimentation and receiver of tellian nappes.

More recent work considers this furrow as a foreland basin acting during all the Miocene. Sedimentary deposits prograde southward with a migration of basin depocenter.

The tellian nappes would then be the cover of the Bibans belt having undergone an important thrusting southward.

New data from seismic, drilling, geochimical modeling and regional documentation show that the geological history of the area is even more complex. These data highlight three major events during the Neogen, contributing closely to the structural architecture of the zone and the organisation of sedimentary deposits. These three events controlled very closely the Ceno-Mesozoïc petroleum system of the Oued gueterini field.

Throughout this study, we'll try to highlight each of these events and their impact on the distribution of sedimentary deposits, as well as the impact on the petroleum system, the maturation, migration and dysmigration of hydrocarbons.

Stratigraphic analysis: The Miocene of Sidi Aïssa area is integrated into three megasequences corresponding to supercycle TB2 according to the nomenclature established by Vail et al (1987). The age of the studied series is lower Miocene Burdigallian; middle Miocene Langhian-Serravalian (Fig 2) Guiraud (1990).

The lower Miocene: It's represented by a low sea-level, starting by an erosive surface case of OGS-I and DEG-1, on which are deposited essentially sandstone-like facies, with some carbonate banks and argillaceous interbeds. Laterally, important variations of thickness and facies are reported. Thus we note that at OGN-1 the thickness of the lower Miocene is very important and decreases gradually towards the south at OGS-1, DEG-1 where the facies becomes more argillaceous.

The middle Miocene: Its represented essentially by transgressive systems tracts and high stand wedges. Therefore we notice that at the Langhian, the detritic influence starting in the lower Miocene weakens, leaving space for black coloured argillaceous deposits, with interbeddings of fine sandstone, silts and marls.

During the serravallian, the transgression reaches its maximum southward, sparing the southern part of the basin considered as an emerged higher zone at this period case of DEG-1 with detrital deposits. In contrast, in the largest part of the basin OGN-1 and OGS-1 a marine sedimentation is developed with deposition of black shales, some marls and marly-limestones.

The spatiotemporal organisation of deposits trending north-south shows a diversification of facies and thikness from black to another. These facts reflect an asymmetrical basins structure with differential subsidence.

The paleogeographic distribution of facies in the middle Miocene following a distal-proximal gradient shows from north to south; Marly-limestones facies of platform; Sandy-argilaceous facies of the front delta than Deltaic plain facies of fluvial and tidal influence.

Structural analysis: During the Miocene the study area has undergone several deformations phases, which are from the oldest to the youngest age.

The phase DI:It's of lower Miocene age (Guiraud, 1997). The main consequense of these phase is the overerection of the Bibans mountains and the setting southward of a foreland basin (Guiraud.R. 1990).

The phase D2: It's of middle Miocene age. During this phase, the whole region undergoes landslides through normal faults linked to transtensionals movements (Mekireche et al 1998). This explains the evolution of coarser facies of lower Miocene into finer facies of middle Miocene age. It's the generalised transgression of Serravalian, marked by onlap detectable on seismics sections (Fig 2). During this period, the Bibans mountains position were enough high to allow the sliding of its Senono-paleogene cover to the south. This later will constitute the tellian nappes, which take place in the south tellain furrow during the Serravalian up to the Tortonian (Guiraud, 1990). 


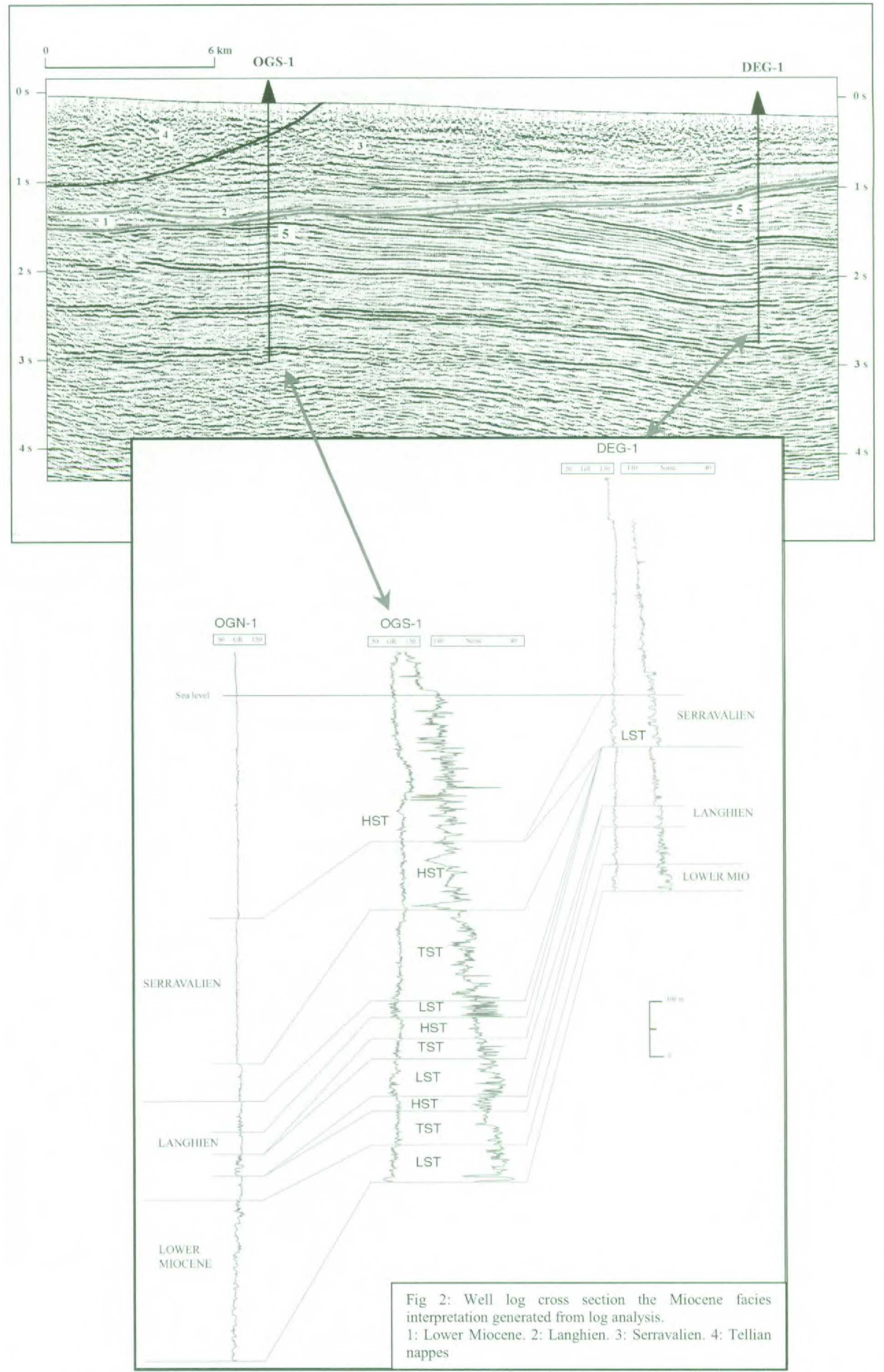


The phase D3: It's of upper Miocène age (Guiraud, 1997). This phase is characterized by structuration of tellian nappes and the autochtonous taking back pre-existing structures risen during previous phases. This is detectable by structures deforming the basal contact of tellian nappes and involving lower and middle Miocene. This structuration results in a generalized emersion witnessed by non-deposition of the upper Miocene..

Burial history: The study area can be divided into two different thermal evolution domains, In the northern zone, the temperature gradients set from Tmax data show that the transition autochtonous / allochtonous is characterized by a shift of lines expressing a thermal unbalance of napped sequences. The ante-nappe sedimentary cover is currently at maximum maturity. The discontinuity between the Cretaceous and the autochtonous Miocene is not checked on the temperature gradient of the drilling of Oued Gueterini. This lack of shifting suggests a late heating and implies that maximum reached during the upper Miocene is synchronous to the setting of tellian nappes. The hydrocarbon generation which may be active to present time, has started in the upper Cretaceous with a paroxysm synchronous to the setting of the tellian nappes.

In the southern zone of the basins the generation of hydrocarbons is later. It also seems sensible to the setting of the tellian nappes. In this zone the beginning of oil generation is synchro-nappes. This state of maturity persisted until the present time.

Conclusion: During the Neogene, the area of Sidi Aïssa was affected by three main events. The first of lower Miocene brings about the initiation of a very brief foreland basin. The second of middle Miocene, is characterized by a distension during which the whole zone acted as an unsymmetrical basin with differential subsidence. This event is rounded up by the setting of tellien nappes. Finally, a third event starting from the upper Miocene which structurates the tellien nappes, as well as their basement. These three events have closely controlled the organisation of sedimentary deposits of the Neogene. Thus the lower Miocene is characterized by coarse-grained deposits in the north running laterally to the south into finer deposits. As for the middle Miocene it shows a paleogeographical distribution according a distalproximal gradient from north to south as follows; Marly-calcairous facies of the platform; Sandyargillaceous facies of the delta front than deltaic facies with tidal to fluvial influence.

The petroleum potentialities of the area are linked to the Cenomano-Turonian which depend on both it's structural position at the time of generation and on it's expulsion effectiveness.

Replacing the tellian nappes in their precise chronologic context, a setting starting from the Langhian up to the Tortonian, we may conclude that the setting of hydrocarbons in the Oued Gueterini field was accomplished from the upper Miocene or from Pliocene.

During the phase D2, a trapping is possible in the structure that rose before or during the middle Miocene. During the phase D3, these structures are totally or partially destroyed resulting in a dysmigration of hydrocarbons across the faults towards the structures of tellian nappes.

Bibliography

Guiraud. R. 1990: L'évolution post-triasique de l'avant-pays de la chaîne alpine en Algérie, d'après l'étude du bassin du Hodna et des régions voisines. Pub ONIG. Mém 3. 259p.

Guiraud. R 1997: the main Mesozoic-Cenozoic tectonic phases along the african-arabian tethyan margin : Abstracts \& Programme an overview. Peri-tethyan programme. ONAREP. Rabat-Morocco. 1012 June. 